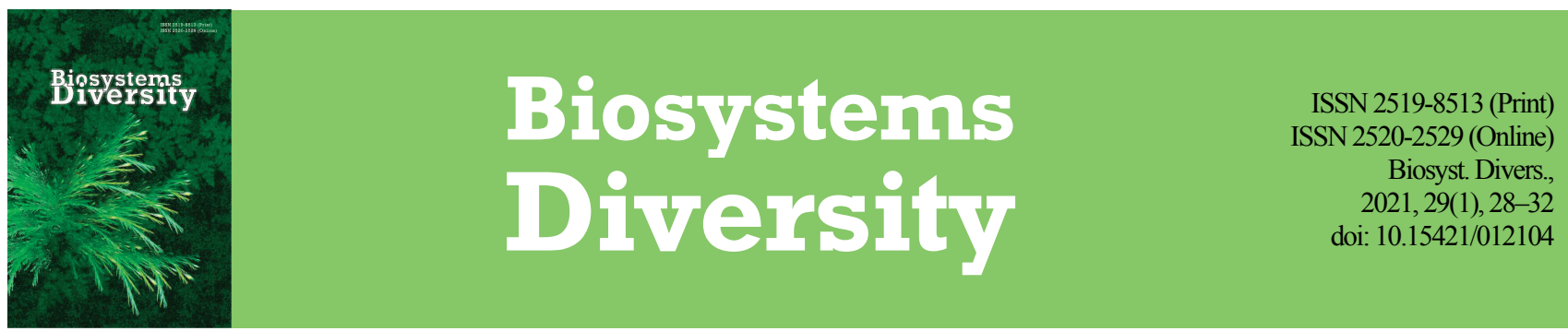

\title{
Genetic structure of rainbow trout Oncorhynchus mykiss (Salmoniformes, Salmonidae) from aquaculture by DNA-markers
}

\author{
O. Y. Bielikova*, A. E. Mariutsa*, A. I. Mruk*, S. I. Tarasjuk*, V. M. Romanenko** \\ *Institute of Fisheries of the National Academy of Agrarian Sciences of Ukraine \\ **National University of Food Technologies, Kyiv, Ukraine
}

Article info

Received 23.01.2021

Received in revised form 16.022021

Accepted 17.02.2021

Institute of Fisherie

of the National Academ

of Agrarian Sciences

of Ukraine,

Obukhivskast., 135 ,

Kyiv, 03164, Ukraine

Tel.: +38-050-772-77-47.

E-mail:

belikova.e.ygmail.com

National University

of Food Technologies,

Volodymyrskast., 68

Kyiv, 01601, Ukraine.

Tel.: +38-050-011-59-49.

E-mail:

13romvik@gmail.com

\begin{abstract}
Bielikova, O. Y., Mariutsa, A. E., Mruk, A. I., Tarasjuk, S. I., \& Romanenko, V. M. (2021). Genetic structure of rainbow trout Oncorhynchus mykiss (Salmoniformes, Salmonidae) from aquaculture by DNA-markers. Biosystems Diversity, 29(1), $28-32$. doi:10.15421/012104
\end{abstract}

The rational use of valuable fish species from aquaculture is difficult to implement without knowledge of the state of the genetic structure of local stocks. Different types of DNA markers can be used to achieve the goals of selection and breeding work. The genetic structure of a local stock of rainbow trout (Oncorhynchus mykiss Walbaum, 1792) (Salmoniformes, Salmonidae) farmed in Ukraine was studied using DNA-markers: microsatellite (SSR-markers - simple-sequence repeats-markers) and intermicrosatellite (ISSR - inter-simple sequence repeat). Five fragments of trinucleotide microsatellite motifs with a single anchor nucleotide at the 3'-end were used as a primer for analysis by the ISSR-PCR method. Totally, 85 amplicons were obtained across the five loci, of which $92.9 \%$ were polymorphic. The total number of alleles ranged from 10 (marker $\left.(\mathrm{ACC})_{6} \mathrm{G}\right)$ to 23 (marker $(\mathrm{AGC})_{6} \mathrm{G}$ ). The following monomorphic amplicons were determined for the studied local stock of rainbow trout: according to marker $(\mathrm{CTC})_{6} \mathrm{C}-770$ and $520 \mathrm{bp}$ bands, for the marker $(\mathrm{GAG})_{6} \mathrm{C}-345,295$ and $260 \mathrm{bp}$, and for the marker (AGC) ${ }_{6} \mathrm{C}-350 \mathrm{bp}$. The average number of polymorphic bands per locus was 15.8 . The selected ISSR primers had a level of polymorphic information content above the average. The most effective markers for molecular-genetic analysis of rainbow trout were $(\mathrm{AGC})_{6} \mathrm{G}$ and $(\mathrm{AGC})_{6} \mathrm{C}$ according to the percentage of polymorphic bands, marker index, effective multiplex ratio and resolving power. The selected ISSR loci allow the genetic structure of the studied local stock to be characterized using the total and the effective number of alleles per locus ( $\mathrm{Na}$ and $\mathrm{Ne}$ were 1.9 and 1.4, respectively), the Shannon index (average value I was 0.4 ) and the unbiased expected heterozygosity (mean uHe $=0.3$ ). Microsatellite-based analysis showed features of the genetic stucture of the local stock of rainbow trout at six microsatellite loci (OMM 1032, OMM 1077, OMM 1088, Str 15, Str 60, Str 73). Allelic diversity was established and alleles with the highest frequency and most typical for the given stock were identified. The Shannon index and unbiased expected heterozygosity were determined using SSR-markers and were 1.42 and 0.79 , respectively. This depicts the complexity of the population structure, a high level of genetic diversity and indicates a high level of heterozygosity of local stock. The "gene pool profile" established as a result of ISSR-PCR in the future will help to differentiate local stocks of rainbow trout in aquaculture of Ukraine. Microsatellite markers provide the ability to determine individual features of genetic variation of local populations and to conduct the management of genetic resources on fish farms.

Keywords: fish population genetics; ISSR-PCR; microsatellite marker; genetic polymorphism; population structure.

\section{Introduction}

Modern methods to control the genetic diversity of local stocks play an important role in increasing efficiency and accelerating breeding work in aquaculture (Chiu et al., 2012). Breeding programs in combination with molecular biology techniques can optimize the use of aquatic genetic resources in aquaculture (Saad et al., 2012). Molecular genetic markers are effective population genetic tools to resolve such issues as mechanisms of adaptation to the environmental condition of fish species, protection of biodiversity, assessment of inbreeding effects and stock identification (Olagunju, 2019). The knowledge of the specifics of the formation of genetic structure will create a platform for obtaining local groups of individuals with the desired economic and valuable characteristics.

The primary task for the development of such programs is the study of polymorphism at the intraspecific level. ISSR-PCR (inter-simple sequence repeats) are one of the most convenient and cheapest tools of molecular genetic analysis for solving this problem. These dominant ISSR-markers allow polylocus genotyping of individuals to be carried out using a single microsatellite locus (Egorova et al., 2018). Multilocus intermicrosatellite analysis (ISSR-PCR) makes it possible to study genetic biodiversity and identify species-specific features, which can be used to create a "gene pool standard" of a breed based on ISSR-fingerprint (Stolpovskii et al., 2010; Labastida et al., 2015; Komarova et al., 2018). Genetic certification becomes an integral part of modern breeding standards and undoubtedly facilitates combating falsifications. ISSR markers are widely used to study various fish species: rainbow trout (Melnikova et al., 2010; Perfilyeva et al., 2018), sterlet (Komarova et al., 2018), tilapia (Saad et al., 2012), cyprinids (Mariutsa et al., 2016). A number of works are devoted to the study of the genetic profile of marine (Yusufzai et al., 2016) and, to a greater extent, exotic fish species, for example, Family Osphronemidae (Abu-Almaaty et al., 2017), Pangasius species (Ly \& Yen, 2019), parrotfish (Saad et al., 2013). In Ukraine, a population genetic analysis using intermicrosatellite loci has already been performed on sturgeon (Dubin, 2012) and cyprinids (Nahorniuk et al., 2013; Hrytsyniak et al., 2015; Mariutsa et al., 2016). However, the rainbow trout cultured in Ukraine has not been studied yet using ISSR markers.

On the other hand, investigations of genetic variability are conducted using microsatellite markers (SSR - simple sequence repeats). They are characterized by wide distribution in the genome, have large allelic polymorphism among individuals and are closely connected with genes of known function. SSR-markers were proven to be essential in studies of the genetic structure of populations for providing management of fish stocks (Olagunju, 2019). Analysis of literature sources in recent years shows that microsatellites were predominantly used in genetic studies of rainbow trout in different countries (Barat et al., 2015; Abadía-Cardoso et al., 2016; Faccenda et al., 2018) to assess the genetic variability of stocks and evaluation of their relationships, reconstruction of the admixture history. Abadía-Cardoso et al. (2016) showed the possibility of identifying the differ- 
ences in natural populations of Oncorhynchus mykiss Walbaum, 1792 from individuals of farmed stocks and assessing the impact on rainbow trout from natural water sources during stocking. Moreover, currently, microsatellites along with SNP-markers (single nucleotide polymorphisms markers) are actively used for the analysis of quantitative trait loci (QTL). It allows determination of the breeding value of individuals, prediction of their productivity at an early age, determination of the efficiency of selection and response to the intensity of selection (Olagunju, 2019).

Therefore, the purpose of our research was to study the genetic profile of rainbow trout in aquaculture of Ukraine using SSR-and ISSR-markers.

\section{Material and methods}

The selection of fish for the study was carried out taking into account the provisions recommended by the European Convention for the Protection of Vertebrate Animals used for Research and other Scientific Purposes (Strasbourg, 1986). The rainbow trout of the Chernivtsi local stock (Berehomet, Chernivtsi region) (Fig. 1) was selected as an object for the study of the genetic structure by ISSR- and SSR-markers. Fin clips were collected from the age-3+ group $(\mathrm{n}=21)$ and stored in $96 \%$ ethanol at a temperature of $4{ }^{\circ} \mathrm{C}$ until DNA isolation. DNA was isolated using a DNAGo commercial kit (BioLabTech LTD). A biophotometer (Eppendorf, Germany) was used to assess the quantity and quality of the isolated DNA.

ISSR genotyping of rainbow trout was performed using five fragments of trinucleotide microsatellite loci (Table 1), which have already been actively studied in other fish species (Dubin, 2012; Nahorniuk et al., 2013; Hrytsyniak et al., 2015; Mariutsa et al., 2016). The following SSRmarkers were used (Table 1): OMM 1032, OMM 1077, OMM 1088
(Rexroad et al., 2002), Str 15, Str 60, Str 73 (Estoup et al., 1993). Amplification was performed on a Thermo Scientific thermocycler (Arktik Thermal Cycler) using the DreamTaq Green PCR Master Mix (2X) (Termo Scientific) under conditions described in Table 1. Amplicons were separated by their molecular weights using electrophoresis in an agarose gel ( $2 \%$ for ISSR- and 3\% for SSR-markers) with ethidium bromide. Band sizes were estimated based on Gene Ruler 1kb DNA Ladder and pUC DNA/Mspl(Hpall) Marker, 23 (Thermo Scientific). The size of the amplified fragments was determined using the TotalLab v.2.01.

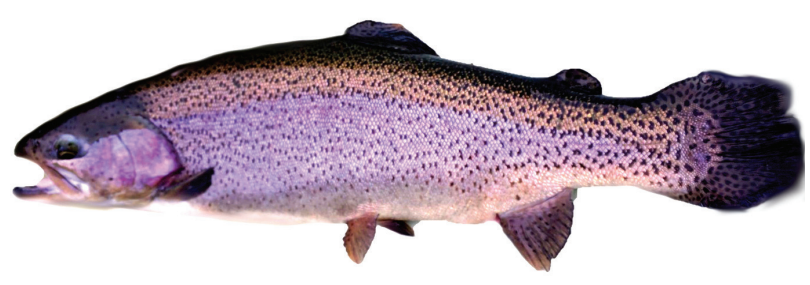

Fig. 1. The phenotype of the rainbow trout cultivated in the local Chernivtsi stock

For further statistical processing, the presence of the ISSR-PCR amplicon was noted as " 1 ", and the absence - as " 0 ". POPGENE version 1.32 (Yeh \& Boyle, 1997) and GenAlEx v 6.5 (Peakall \& Smouse, 2006, 2012) were used to determine the number of alleles per locus $(\mathrm{Na})$, effective number of alleles per locus (Ne), Shannon's information index (I), unbiased expected heterozygosity $(\mathrm{uHe})$, and the percentage of polymorphic loci (PPL).

Table 1

ISSR- and SSR-markers used in the study of Oncorhynchus mykiss, sequences of primers and amplification conditions

\begin{tabular}{|c|c|c|c|c|c|c|c|c|c|}
\hline $\begin{array}{l}\text { Type of } \\
\text { marker }\end{array}$ & $\begin{array}{c}\text { Symbol/ } \\
\text { Locus }\end{array}$ & Repeat Motif & Sequence $\left(5^{\prime}-3^{\prime}\right)$ & $\mathrm{iD}$ & Cycles & $\mathrm{D}$ & AT & $\mathrm{E}$ & $\mathrm{fE}$ \\
\hline \multirow{5}{*}{ 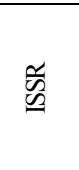 } & $\mathrm{A}$ & $(\mathrm{CTC})_{6} \mathrm{C}$ & 5'-СТС СТС СТС СТС СТC СТC C-3' & $95^{\circ} \mathrm{C} 2 \mathrm{~min}$ & 32 & $94^{\circ} \mathrm{C} 30 \mathrm{~s}$ & $60^{\circ} \mathrm{C} 30 \mathrm{~s}$ & $72^{\circ} \mathrm{C} 2 \mathrm{~min}$ & $72^{\circ} \mathrm{C} 10 \mathrm{~min}$ \\
\hline & $\mathrm{B}$ & $(\mathrm{GAG})_{6} \mathrm{C}$ & 5'-GAGGAGGAGGAGGAGGAGC-3' & $"$ & $"$ & $"$ & $58^{\circ} \mathrm{C} 30 \mathrm{~s}$ & $"$ & $"$ \\
\hline & $\mathrm{C}$ & $(\mathrm{AGC})_{6} \mathrm{G}$ & 5' - AGC AGC AGC AGC AGC AGC G-3' & $"$ & $"$ & $"$ & $58^{\circ} \mathrm{C} 30 \mathrm{~s}$ & $"$ & $"$ \\
\hline & $\mathrm{D}$ & $(\mathrm{ACC})_{6} \mathrm{G}$ & 5' - ACC ACC ACC ACC ACC ACC G -3' & $"$ & $"$ & $"$ & $58^{\circ} \mathrm{C} 30 \mathrm{~s}$ & $"$ & $"$ \\
\hline & $\mathrm{E}$ & $(\mathrm{AGC})_{6} \mathrm{C}$ & 5' - AGC AGC AGC AGC AGC AGCC -3' & " & $"$ & $"$ & $60^{\circ} \mathrm{C} 30 \mathrm{~s}$ & $"$ & " \\
\hline \multirow{6}{*}{$\tilde{\text { र्: }}$} & OMM 1032 & $(\mathrm{AG})_{22}$ & $\begin{array}{c}\text { F:GCGAGGAAGAGAAAGTAGTAG } \\
\text { R:CCCATCTTCTCTCTGATTATG }\end{array}$ & $94^{\circ} \mathrm{C} 10 \mathrm{~min}$ & 35 & $94^{\circ} \mathrm{C} 30 \mathrm{~s}$ & $58^{\circ} \mathrm{C} 30 \mathrm{~s}$ & $72^{\circ} \mathrm{C} 30 \mathrm{~s}$ & $72^{\circ} \mathrm{C} 5 \mathrm{~min}$ \\
\hline & OMM 1077 & $(\mathrm{GATA})_{9}$ & $\begin{array}{l}\text { F:GGCTGACCAGAGAAAGACTAGTTC } \\
\text { R:TGTTACGGTGTCTGACATGC }\end{array}$ & $"$ & " & $"$ & $"$ & $"$ & $"$ \\
\hline & OMM 1088 & $(\text { GATA })_{12}$ & $\begin{array}{l}\text { F:CTACAGGCCAACACTACAATC } \\
\text { R:CTATAAAGGGAATAGGCACCT }\end{array}$ & $"$ & $"$ & $"$ & $"$ & " & " \\
\hline & $\begin{array}{c}\text { Str } 15 \\
\text { (MST-15)* }\end{array}$ & $(\mathrm{GT})_{13}$ & $\begin{array}{c}\text { F:TGCAGGCAGACGGATCAGGC } \\
\text { R:AATCCTCTACGTAAGGGATTTGC }\end{array}$ & $94^{\circ} \mathrm{C} 5$ min & 30 & $"$ & $"$ & $"$ & $72^{\circ} \mathrm{C} 10 \mathrm{~min}$ \\
\hline & $\begin{array}{c}\text { Str } 60 \\
\text { (MST-60)* }\end{array}$ & $(\mathrm{CT})_{13} \mathrm{ACCA}(\mathrm{CT})_{3}$ & $\begin{array}{l}\text { F:CGGTGTGCTTGTCAGGTTTC } \\
\text { R:GTCAAGTCAGCAAGCCTCAC }\end{array}$ & $"$ & $"$ & $"$ & $"$ & $"$ & $"$ \\
\hline & $\begin{array}{c}\text { Str73 } \\
(\mathrm{MST}-73)^{*} \\
\end{array}$ & $(\mathrm{GT})_{13} \mathrm{TTATCT}(\mathrm{GT})_{3}$ & $\begin{array}{c}\text { F:CCTGGAGATCCTCCAGCAGGA } \\
\text { R:CTATTCTGCTTGTAACTAGACCTA }\end{array}$ & $"$ & $"$ & $"$ & $"$ & $"$ & $"$ \\
\hline
\end{tabular}

Notes: * - sequences registered in GenBank according to the name used in the reference (Presa \& Guyomard, 1996); F - forward primer's sequence; R - reverse primer's sequence; $\mathrm{DD}$ - initial DNA denaturation; D - denaturtion; AT - annealing temperature; E - extension; $\mathrm{fE}$ - final elongation; " - conditions are similar to those indicated in this column above.

The Polymorphism Information Content (PIC) was assessed using methods (Nagy et al., 2012) generally accepted for codominant markers and the GDdom for ISSR-markers (Abuzayed et al., 2016). The following parameters were used to determine the information content of ISSR primers: effective multiplex ratio (EMR), marker index (MI), resolving power (Rp), which were calculated using methods (Prevost \& Wilkinson, 1999).

\section{Results}

A total of 85 amplicons was obtained by genotyping rainbow trout with the use of five ISSR markers and $92.9 \%$ of the amplicons were polymorphic (Table 2). The molecular weight of the amplified fragments ranged from 170 to $1900 \mathrm{bp}$ (Fig. 2). Amplicon size and their frequencies show the "gene pool profile" of rainbow trout cultivated in aquaculture of Ukraine by ISSR-markers. The total number of amplicons per locus (NTB) ranged from 10 (marker D and B) to 23 (marker C). For three of the five studied loci, 6 conservative bands, or so-called monomorphic bands were identified, the number of which ranged from 1 to 3 per locus. For marker A, these were amplicons with a molecular weight of 770 and $520 \mathrm{bp}$, for marker B - 345, 295 and $260 \mathrm{bp}$, and for marker E-350 bp.

The mean value of alleles per locus and the effective number of alleles were $1.92 \pm 0.04$ and $1.45 \pm 0.02$, respectively. The average value of the Shannon index was $0.43 \pm 0.02$ (Fig. 3), and the unbiased expected heterozygosity was $0.30 \pm 0.01$.

The average number of polymorphic bands per locus was $15.8 \pm 2.6$. A high percentage of polymorphic bands was observed by the selected intermicrosatellite markers (average PPB $=92.2 \%$ ). The highest percentage of polymorphic fragments was observed by using the marker (AGC) 6 G and (ACC) 6 G (100.0\%), the lowest by $(\mathrm{GAG})_{6} \mathrm{C}(76.9 \%)$.

The polymorphism information content ranged from 0.246 (marker B) to 0.309 (marker E) with a mean value 0.2419 . The efficiency of the "primer-marker system" increases according to an increase in EMR values; in our studies, the EMR value ranged from 7.7 (marker B) to 23.0 
(marker C). The marker index, which serves as a general measure of the usefulness of the marker system, increased in this order $\mathrm{B}<\mathrm{D}<\mathrm{A}<\mathrm{E}<$ $\mathrm{C}$. The resolution power (Rp) of the selected ISSR loci grew in the sequence $\mathrm{D}<\mathrm{B}<\mathrm{A}<\mathrm{C}<\mathrm{E}$.

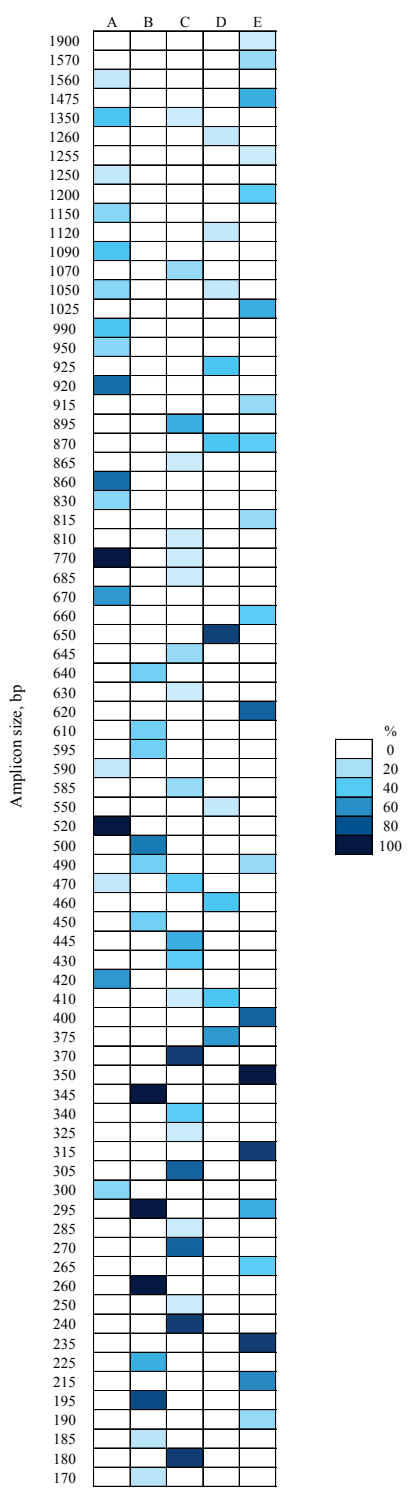

Fig. 2. Amplicon lengths and their frequencies (\%) obtained using ISSR-markers: $\mathrm{A}-(\mathrm{CTC})_{6} \mathrm{C}, \mathrm{B}-(\mathrm{GAG})_{6} \mathrm{C}$, $\mathrm{C}-(\mathrm{AGC})_{6} \mathrm{G}, \mathrm{D}-(\mathrm{ACC})_{6} \mathrm{G}, \mathrm{E}-(\mathrm{AGC})_{6} \mathrm{C}$

Microsatellite-based analysis. Allelic diversity and frequency for the listed six microsatellite loci represent features of the genetic structure of the local stock of rainbow trout (Fig. 4). Alleles with the highest frequency were identified: a $253 \mathrm{bp}$ allele (50\%) at the OMM 1032 locus, a 319 bp allele (42.9\%) at the Str 15 locus, and a 140 bp allele (37.5\%) at the Str 60 locus. The highest number of alleles per locus $(\mathrm{Na})$ was observed at the locus OMM 1077; for other loci, this parameter was 5 alleles (OMM 1088 and Str 60) and 4 alleles (OMM 1032, Str 15, Str 73). The average $\mathrm{Na}$ was $4.67 \pm 0.33$. According to value effective number of alleles per locus $(\mathrm{Ne})$, the selected SSR loci are arranged in the following order OMM $1032<$ Str $15<$ Str $73<$ Str $60<$ OMM $1088<$ OMM 1077 (Fig. 5), mean value was $3.88 \pm 0.32$. As a result of microsatellite analysis, the calculated Shannon index ranged from 1.21 to 1.67 with an average value of $1.42 \pm 0.07$. The unbiased expected heterozygosity was fixed at the level of $0.70-0.85$ (average $0.79 \pm 0.02$ ).

The determined parameters of genetic diversity of the local stock of rainbow trout using ISSR-markers varied in narrow ranges, e.g., Na ranged from 1.8 to $2.0 ; \mathrm{Ne}=1.39-1.52$. Fluctuations of the Shannon index were observed in the range $0.38-0.48$, and unbiased expected heterozy- gosity uHe varied in the range from 0.25 to 0.32 . This suggests that each ISSR-marker can be used separately to quickly monitor the genetic diversity of local stocks.

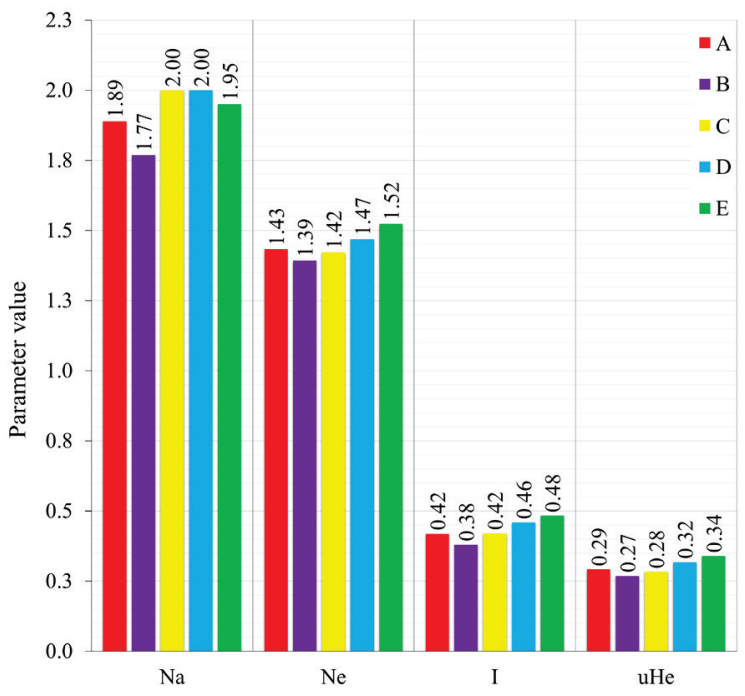

Fig. 3. Number of alleles per locus (Na), effective number of alleles per locus (Ne), Shannon's information index (I), unbiased expected heterozygosity $(\mathrm{uHe})$ determined by studied ISSR-markers

\section{Discussion}

The genetic profile of rainbow trout cultivated in aquaculture of Ukraine was determined using five ISSR markers and six microsatellite (SSR) markers. The efficiency of the selected ISSR-primers, which consisted of trinucleotide microsatellite motifs with a single anchor nucleotide at the 3'-end, was tested. Reddy et al. (2002) emphasized that it is better to use primers with an anchor region (3'- or 5'-anchored) since annealing, in this case, extends only to the ends of microsatellites in the DNA template, preventing the formation of smears instead of clear amplicons, which is due to slippage along the length of complementary microsatellite region during PCR. Taking into account that PIC $\leq 0.5$ (Chesnokov \& Artemyeva, 2015) for dominant markers, it can be concluded that the studied ISSR-markers had the value of the information polymorphism content above average. The highest PPB, EMR and MI rates were recorded for markers (AGC) $)_{6} \mathrm{G}$ and $(\mathrm{AGC})_{6} \mathrm{C}$. Based on the value of the resolving power, it was found that the (AGC) ${ }_{6} \mathrm{C}$ marker shows the highest ability to identify differences between a large number of genotypes. As for the effectiveness of the microsatellite markers used, we previously demonstrated that the polymorphism information content exceeded the level of 0.5 (the average PIC was $0.70 \pm 0.03$ ), which for codominant markers indicates a high level for this parameter. Barat et al. (2015) in their study used other markers of the OMM group, which were also originally developed by Rexroad et al. (2002). The markers indicated a high allelic variability and showed their availability to analyze the genetic structure of rainbow trout stocks in India.

The specificity of the allelic profile determined by each of the ISSRmarkers (Fig. 2) was established, which is a consequence of the specificity of the genotypes of rainbow trout of local stock in aquaculture of Ukraine and the nucleotide sequence of the primer. Studying the distribution of lengths of amplification products in individuals from different stocks will allow monitoring of the differentiation and consolidation of the genetic structure of rainbow trout on individual farms and assessing the genealogical relationships among them.

In further works, the difference between the profiles of various natural and artificial local stocks by specific amplicons obtained in ISSR analysis will allow differentiation of different rainbow trout populations. For example, as shown by Komarova et al. (2018), it was possible to effectively distinguish the sterlet populations by the presence of specific alleles, since only fish from the Vyatka River (middle course) had 780 bp amplicons determined for the primer (ACC) 6 G. 
Table 2

Parameters of polymorphism of the genetic structure of rainbow trout and the information content of ISSR markers

\begin{tabular}{ccccccccc}
\hline Primer & $\begin{array}{c}\text { Fragment } \\
\text { length, bp }\end{array}$ & $\begin{array}{c}\text { Number of total } \\
\text { bands (NTB) }\end{array}$ & $\begin{array}{c}\text { Number of polymorphic } \\
\text { bands (NPB) }\end{array}$ & $\begin{array}{c}\text { Percentage of polymorphic } \\
\text { bands (PPB), \% }\end{array}$ & $\begin{array}{c}\text { Polymorphic information } \\
\text { content (PIC), } \pm \pm \text { SE }\end{array}$ & $\begin{array}{c}\text { Effective multiplex } \\
\text { ratio (EMR) }\end{array}$ & $\begin{array}{c}\text { Marker } \\
\text { index (M) }\end{array}$ & $\begin{array}{c}\text { Resolving } \\
\text { power (Rp) }\end{array}$ \\
\hline $\mathrm{A}$ & $300-1560$ & 18 & 16 & 88.9 & $0.270 \pm 0.037$ & 14.2 & 3.8 & 15.7 \\
$\mathrm{~B}$ & $170-640$ & 13 & 10 & 76.9 & $0.246 \pm 0.048$ & 7.7 & 1.9 & 14.0 \\
$\mathrm{C}$ & $180-1350$ & 23 & 23 & 100.0 & $0.265 \pm 0.031$ & 23.0 & 6.1 & 16.5 \\
$\mathrm{D}$ & $375-1260$ & 10 & 10 & 100.0 & $0.295 \pm 0.044$ & 10.0 & 2.9 & 7.4 \\
$\mathrm{E}$ & $190-1900$ & 21 & 20 & 95.2 & $0.309 \pm 0.031$ & 19.0 & 5.9 & 19.0 \\
\hline $\mathrm{X} \pm \mathrm{SE}$ & - & $17.0 \pm 2.4$ & $15.8 \pm 2.6$ & $92.2 \pm 4.3$ & $0.242 \pm 0.010$ & $14.8 \pm 2.8$ & $4.1 \pm 0.8$ & $14.5 \pm 2.0$ \\
\hline
\end{tabular}

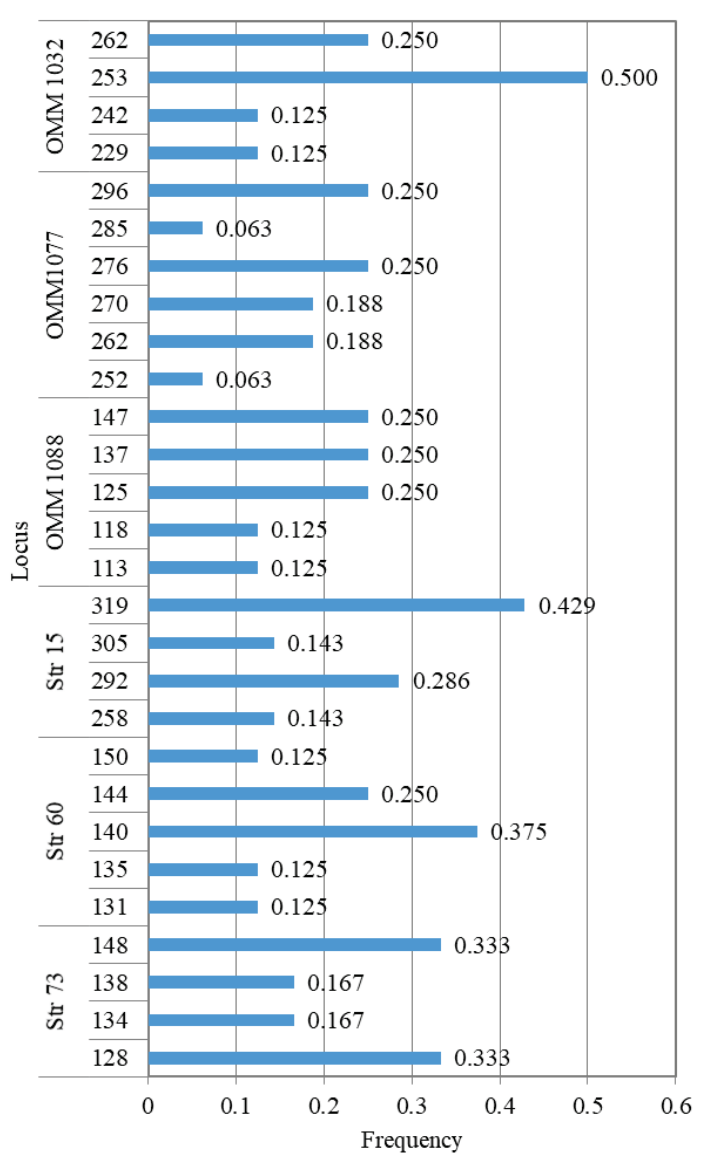

Fig. 4. Frequencies of alleles of rainbow trout at six microsatellite loci

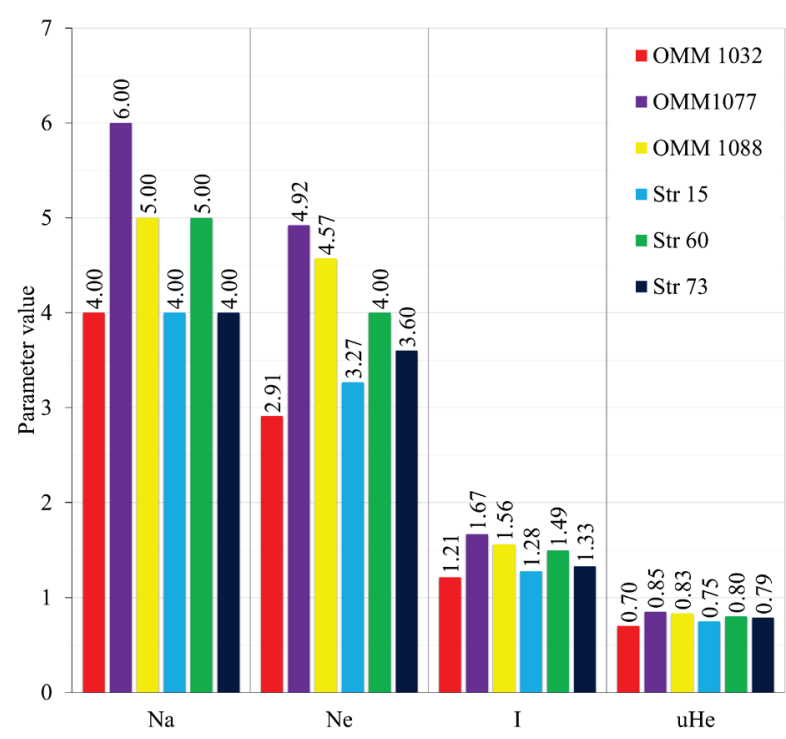

Fig. 5. Number of alleles per locus (Na), effective number of alleles per locus (Ne), Shannon's information index (I), unbiased expected heterozygosity (uHe) determined by the studied SSR-markers
Perfilyeva et al. (2018) found a species-specific allele (400 bp) for a Kazakhstan population of rainbow trout using markers $(\mathrm{CAG})_{7} \mathrm{~T}$ and $(\mathrm{CAG})_{5}$. Several studies (Melnikova et al., 2010; Komarova et al., 2018; Perfilyeva et al., 2018), which were carried out on rainbow trout using intermicrosatellite loci, are indicative of the fact that ISSR-markers are promising for intraspecific differentiation of populations. As noted by Sulimova et al. (2011), the information content and convenience of the analysis using ISSR-PCR method has increased due to the development of software for statistical processing of results, such as, for example, Structure. Stolpovskii et al. (2010) used ISSR loci to analyze the genetic structure and determine the so-called "gene pool profile" and "gene pool standard". It's possible to determine the correspondence of the genetic structure of individuals to the gene pool standard according to the major bands and amplicon frequencies, which occurred with a high frequency (more than $40.0 \%$ ), as well as further cluster analysis. Studies in this field, as shown in some works (Sulimova et al., 2011; Komarova et al., 2018), allows ISSR-markers to be used to create genetic passports of breeds or intrabreed types. Therefore, at the present stage, intermicrosatellite analysis is highly informative, universal and indicative for the study of biodiversity and identification of differences in animal populations.

At the same time, Faccenda et al. (2017) showed that the results of microsatellite analysis were essential to understanding the state of genetic resources of each individual stock. Since, in addition to significant genetic variation within populations, there is also significant subdivision reflected at the inter-population level. Faccenda et al. (2017) concluded that it was possible to give recommendations on the rational management of local stocks for breeding pure bred broodstocks based on the data of the SSRanalysis. Faccenda et al. (2017) showed that OMM markers (including the OMM 1088 marker used in our work) were promising for effective work with local stocks for their differentiation.

We concluded that ISSR markers are convenient for interspecies identification and creation of genetic passports since they are universal in this aspect and are applicable for different animal species. Microsatellite markers are more convenient for identifying intraspecific polymorphism of rainbow trout and can be used as routine tools for solving the goals of fish farming at the current level of the development of molecular genetic methods.

\section{Conclusion}

The information content of ISSR primers for studying the gene pool of rainbow trout and monitoring its state was determined. The genetic profile of rainbow trout by ISSR- and SSR-markers has been obtained, which will allow intra- and interspecific identification to be carried out, and gene pool standards of breed to be introduced in the future that will be developed and approved in Ukraine. The obtained results indicate that the DNA markers used may be useful for monitoring the genetic diversity and inbreeding rate of local stocks of rainbow trout in aquaculture.

The study was supported by the Fund of Fundamental and Applied Research of the National Academy of Agrarian Sciences of Ukraine on the subject 37.00.01.05 F "To study the mechanisms of adaptation of certain valuable fish species using methods of population genetics" (DR No 0116U001227) and 33.00.00.19 P "To investigate the genetic variability of rare and endangered species of salmon and sturgeon fish in the water bodies of the Carpathian region and to develop methods for their reproduction" (DR No 0119U100578) in 2016-2020. We are also grateful to the trout farm for the materials provided. 


\section{References}

Abadía-Cardoso, A., Pearse, D. E., Jacobson, S., Marshall, J., Dalrymple, D., Kawasaki, F., Ruiz-Campos, G., \& Garza, J. C. (2016). Population genetic structure and ancestry of steelhead/rainbow trout (Oncorhynchus mykiss) at the extreme southern edge of their range in North America. Conservation Genetics, 17(3), 675-689.

Abu-Almaaty, A. H., Hassan, M. K., Bahgat, I. M., \& Suleiman, M. E. E. (2017). Inter simple sequence repeat (ISSR) and cytogenetic analysis of three fish species of family Osphronemidae. Egyptian Journal of Aquatic Biology and Fisheries, 21(2), $1-15$.

Abuzayed, M., El-Dabba, N., Frary, A., \& Doganlar, S. (2016). GDdom: An online tool for calculation of dominant marker gene diversity. Biochemical Genetics, 55(2), 155-157.

Barat, A., Sahoo, P. K., Kumar, R., Mir, J. I., Ali, S., Patiyal, R. S., \& Singh, A. K (2015). Molecular characterization of rainbow trout, Oncorhynchus mykiss (Walbaum, 1792) stocks in India. Journal of Genetics, 94(S2), 13-18.

Bielikova, O. Y., Zaloilo, O., Tarasjuk, S., Mruk, A., \& Romanenko, V. (2019). Henetychna struktura raiduzhnoi foreli (Oncorhynchus mykiss) chernivetskoho lokalnoho stada za SSR-markeramy [Genetic structure of the Chernivtsi local stock of rainbow trout (Oncorhynchus mykiss) as determined by SSR-markers]. Faktori Eksperimental'noi Evolucii Organizmiv, 25, 26-31 (in Ukrainian).

Chesnokov, Y. V., \& Artemyeva, A. M. (2015). Evaluation of the measure of polymorphism information of genetic diversity. Agricultural Biology, 50(5), 571-578.

Chiu, T.-H., Su, Y.-C., Lin, H.-C., \& Hsu, C.-K. (2012). Molecular electrophoretic technique for authentication of the fish genetic diversity. In: Magdeldin, S. (Ed.) Gel electrophoresis - advanced techniques. InTech, Rijeka. Pp. 83-96.

Dubin, O. V. (2012). Amplifikatsiia mizhmikrosatelitnykh poslidovnostei yak metod otsiniuvannia polimorfizmu populiatsii azovskoi sevriuhy [Amplification of intermicrosatellite sequences as a method of estimating polymorphism of the Azov sturgeon population]. Bulletin of Zhytomyr National Agroecological University, 2(1), 129-133 (in Ukrainian).

Egorova, K. I., Glazko, V. I., Shumilina, A. R., Kosovkiy, G. Y. (2018). Geneticheskaya struktura trekhporodnogo krossa po sravneniyu s iskhodnymi porodami krolika [Genetic structure of three-way cross of rabbits in comparison with parental breeds]. Agrarian Scientific Journal, 6, 7-10 (in Russian).

Estoup, A., Presa, P., Krieg, F., Vaiman, D., \& Guyomard, R. (1993). (CT) and (GT) microsatellites: A new class of genetic markers for Salmo trutta L. (brown trout). Heredity, 71, 488-496.

Faccenda, F., Lunelli, F., Gandolfi, A., \& Bozzi, R. (2018). Microsatellite-based genetic diversity and admixture history of rainbow trout (Oncorhynchus mykiss Walbaum, 1792) stocks in Trentino (Italy). Turkish Joumal of Fisheries and Aquatic Sciences, 18(7), 881-889.

Hrytsyniak, I., Mariutsa, A., \& Tarasyuk, S. (2015). Henetychna struktura okremykh pleminnykh stad strokatoho tovstolobyka [The genetic structure of individual groups of bighead carp (Hypophtalmichthys nobilis)]. Fisheries Science of Ukraine, 32, 41-50 (in Ukrainian).

Komarova, L. V., Kostitsyna, N. V., Boronnikova, S. V., \& Melnikova, A. G. (2018). Genetic structure of natural populations of sterlet (Acipenser ruthenus L.) in the catchment basins of the Kama and Ob rivers based on polymorphic ISSR markers. Agricultural Biology, 53(2), 337-347.

Labastida, E., Cobián, D., Hénaut, Y., del Carmen García-Rivas, M., Chevalier, P. P., \& MacHkour-M'rabet, S. (2015). The use of ISSR markers for species determination and a genetic study of the invasive lionfish in Guanahacabibes, Cuba. Latin American Journal of Aquatic Research, 43(5), 1011-1018.

Ly, T. T. M., \& Yen, D. T. (2019). Differentiation of two Pangasius species, Pangasius krempfi and Pangasius mekongensis using inter-simple sequence repeat markers. International Journal of Fisheries and Aquatic Studies, 7(4), 116-120.

Mariutsa, A., Tarasjuk, S., \& Hrytsyniak, I. (2016). Analiz henetychnoi struktury okremykh typiv ukrainskoho luskatoho koropa [Analysis of the genetic stucture of certain types of scaled carp]. Ribogospodars'ka Nauka Ukraïni, 38, 113-122 (in Ukrainian).
Melnikova, M. N., Senchukova, A. L., \& Pavlov, S. D. (2014). Introduction of ISSR markers for Kamchatka mykiss (Parasalmo (Oncorhynchus) mykiss) (Walbaum) (Salmonidae, Salmoniformes). Doklady Biochemistry and Biophysics, 459(1), 209-213.

Nagy, S., Poczai, P., Cernák, I., Gorji, A. M., Hegedűs, G., \& Taller, J. (2012). PICcalc: An online program to calculate polymorphic information content for molecular genetic studies. Biochemical Genetics, 50, 670-672.

Nahorniuk, T. A., Zaloilo, O. V., \& Tarasiuk, S. I. (2013). Analiz henetychnoi struktury koropa antoninsko-zozulenetskoho typu [Analysis of the genetic structure of Antonin-Zozulen type carp]. Visnyk Agramoi Nauky, 9, 36-40 (in Ukrainian)

Olubunmi, O. O. (2019). Application of microsatellite in fish biotechnology: Prospects and drawback - review. International Journal of Bioengineering and Biotechnology, 4(3), 37-43.

Peakall, R., \& Smouse, P. (2012). GenAlEx 6.5: Genetic analysis in Excel. Population genetic software for teaching and research - an update. Bioinformatics, 28(19), 2537-2539.

Peakall, R., \& Smouse, P. E. (2006). Genalex 6: Genetic analysis in Excel. Population genetic software for teaching and research. Molecular Ecology Notes, 6(1), 288-295.

Perfilyeva, A. V., Mynbayeva, B. N., Tanybaeva, A. K., Myzdybaeva, K. K., Ualiyeva, D. A., Abdikarym, S. E., \& Bekmanov, B. O. (2018). Molecular and genetic characteristics of Kazakhstani Rainbow trout with ISSR-PCR analaysis. News of the National Academy of Sciences of the Republic of Kazakhstan, Series of Biological and Medical, 325, 44-50.

Powell, W., Morgante, M., Andre, C., Hanafey, M., Vogel, J., Tingey, S., \& Rafalski, A. (1996). The comparison of RFLP, RAPD, AFLP and SSR (microsatellite) markers for germplasm analysis. Molecular Breeding, 2(3), 225-238.

Presa, P., \& Guyomard, R. (1996). Conservation of microsatellites in three species of salmonids. Journal of Fish Biology, 49(6), 1326-1329.

Prevost, A., \& Wilkinson, M. J. (1999). A new system of comparing PCR primers applied to ISSR fingerprinting of potato cultivars. Theoretical and Applied Genetics, 98(1), 107-112

Reddy, P. M., Sarla, N., \& Siddiq, E. A. (2002). Inter simple sequence repeat (ISSR) polymorphism and its application in plant breeding. Euphytica, 128(1), 9-17.

Rexroad, C. E., Coleman, R. L., Hershberger, W. K., \& Killefer, J. (2002). Rapid communication: Thirty-eight polymorphic microsatellite markers for mapping in rainbow trout. Journal of Animal Science, 80(2), 541-542.

Saad, Y. M., AbuZinadah, O. A. H., \& El-Domyati, F. (2013). Monitoring of genetic diversity in some parrotfish species based on inter simple sequence repeats polymorphism. Life Science Journal, 10(44), 1841-1846.

Saad, Y. M., Rashed, M. A., Atta, A. H., \& Ahmed, N. (2012). Genetic diversity among some tilapia species based on ISSR markers. Life Science Journal, 9(4), 4841-4846.

Stolpovskii, Y. A., Lazebny, O. E., Stolpovskii, K. Y., \& Sulimova, G. E. (2010). The use of the ISSR-PCR method for identifying domesticated animal breeds and species, inferring their population stuctures, and assessing gene pool similarity. Russian Joumal of Genetics, 46(6), 732-739.

Sulimova, G., Kol, N., Rusina, M., Stolpovsky, K., Voronkova, V., Boyarintseva, I., \& Stolpovsky, Y. (2011). Razrabotka universal'nogo metoda ocenki geneticheskogo raznoobraziya i pasportizacii porod i populyacij domesticirovannyh vidov zhivotnyh [Development of a universal method for estimation of genetic diversity and certification of domesticated animal species and populations]. Molekulyamaya i Prikladnaya Genetika, 12, 19-27 (in Russian).

Yeh, F. C., \& Boyle, T. J. B. (1997). Population genetic analysis of co-dominan and dominant markers and quantitative traits. Belgian Journal of Botany, $129,157-163$

Yusufzai, S. I., Padhiyar Shital, M., Smit, L., Tomar Rukam, S., Thummar Vibha, D., Thakkar Jalpa, R., Rathod Visha, M., Kheni Jasmin, V., Vishal, K., Parakhia, M. V., \& Golakiya, B. A. (2016). Genetic diversity analysis in some marine fish species of Gujarat coast through morphological and molecular markers. Research Journal of Biotechnology, 11(3), 77-84. 